\title{
Bovine Intramammary Infections Caused by Coagulase-Negative Staphylococci May Persist Throughout Lactation According to Amplified Fragment Length Polymorphism-Based Analysis
}

\author{
S. Taponen, ${ }^{\star 1}$ J. Koort,† J. Björkroth,‡ H. Saloniemi, ${ }^{*}$ and S. Pyörälä* \\ *Department of Production Animal Medicine, \\ †Department of Basic Veterinary Sciences, and \\ ‡Department of Food and Environmental Hygiene, University of Helsinki, 00014 Helsinki, Finland
}

\begin{abstract}
Persistence of coagulase-negative staphylococci (CNS) in intramammary infections during lactation was studied in a research dairy herd of University of Helsinki. Milk samples from 328 udder quarters of 82 dairy cows (30 primiparous, 52 multiparous) were collected $2 \mathrm{wk}$ before calving, at calving, and every $4 \mathrm{wk}$ thereafter until the end of lactation or until the cow left the herd. The CNS isolated from the milk samples were analyzed with the API Staph ID 32 (bioMérieux, Marcy l'Etoile, France) test (API) and genotyped using amplified fragment length polymorphism (AFLP) analysis. The AFLP patterns were used for similarity analysis between CNS isolates and for species identification. For the latter, AFLP patterns of CNS isolates and staphylococcal type strains were used as operational taxonomic units in numerical analysis. In addition, the somatic cell count (SCC) of the milk samples was measured during lactation. A CNS infection was considered persistent when isolates originating from the same quarter had identical AFLP patterns on at least 3 consecutive samplings. In total, 63 CNS infections were detected during lactation in 30 and 33 quarters in the first and later lactations, respectively. Twenty-nine of these infections persisted and 34 were transient. Most of the persistent infections lasted until the end of lactation. In 57 quarters, CNS infection was detected before calving, at calving, or both, but only half of these quarters were infected by CNS during subsequent lactation. The geometric mean of SCC in quarters during persistent CNS infection was 657,600 cells $/ \mathrm{mL}$, and the mean of SCC in quarters with transient CNS infection was 619,100 cells $/ \mathrm{mL}$. The median of SCC in quarters during persistent CNS infection was 355,400 cell $\mathrm{s} / \mathrm{mL}$, and the median of SCC in quarters with transient CNS
\end{abstract}

Received December 19, 2006.

Accepted March 30, 2007.

${ }^{1}$ Corresponding author: suvi.taponen@helsinki.fi infection was 133,500 cells $/ \mathrm{mL}$. According to both the API test and AFLP results, Staphylococcus chromogenes and Staphylococcus simulans were the CNS species isolated most often. Identification results for API and AFLP corresponded in $71.9 \%$ of the isolates.

Key words: mastitis, bovine, persistent, coagulasenegative staphylococci

\section{INTRODUCTION}

Coagulase-negative staphylococci in dairy production are often considered pathogens of minor importance, especially in contrast to Staphylococcus aureus, streptococci, and coliforms, which may cause severe mastitis. In many countries, CNS are the predominant pathogens associated with mastitis (Waage et al., 1999; Macovec and Ruegg, 2003; Nevala et al., 2004) and isolated in the prevalence studies (Wilson et al., 1997; Pitkälä et al., 2004; Tenhagen et al., 2006). For reasons not yet known, CNS infection is especially common in heifers (Honkanen-Buzalski et al., 1994; Aarestrup and Jensen, 1997). Mastitis caused by CNS usually remains subclinical or mildly clinical (Taponen et al., 2006), but may slightly decrease milk production (Timms and Schultz, 1987; Gröhn et al., 2004; De Vliegher et al., 2005). Gröhn et al. (2004) have shown that multiparous cows with clinical CNS mastitis were, before the onset of mastitis, higher producers than control cows without CNS mastitis and that milk production losses may have been previously underestimated.

Quality requirements for raw milk are high and the price of bulk tank milk is often connected to the SCC of the milk. In Finland, the requirement for best bulk milk price is SCC $<250,000$ cells $/ \mathrm{mL}$ and bacterial count $<50,000 / \mathrm{mL}$. Dairy producers pay much attention to keeping the SCC low; any bacteria persisting in the udder and increasing the SCC are, in this respect, harmful. Although CNS infections are commonly thought to be self limiting, this may not always be the case. There is some evidence that CNS infection may persist in the udder for a long time, even for the entire 
lactation (Aarestrup and Jensen, 1997; Laevens et al., 1997a; Chaffer et al., 1999; Taponen et al., 2006).

Our aim was to investigate the persistence of CNS in the udder of lactating cows over the entire lactation period using consecutive sampling and phenotyping and genotyping of the isolates. The influence of CNS infection on the milk SCC was also examined.

\section{MATERIALS AND METHODS}

The study was conducted in the dairy herd of the University of Helsinki. The herd comprised about 80 lactating cows kept in a tie stall. Most of the cows were of Finnish Ayrshire breed and a few were Holstein Friesians. The average milk production of the herd in 2004 was $11,263 \mathrm{~kg} / \mathrm{cow}$ per year. The cows were milked twice a day. A total of 82 animals (30 heifers and 52 cows) that calved during the autumn of 2003 and at the beginning of 2004 were included. Twenty-one, 15, 5 , and 11 cows calved for a second, third, fourth, or fifth or more time, respectively. During the study period, no cows with CNS infection received antimicrobial treatment. Some cows were treated because of mastitis caused by other bacteria than CNS but were not included in any calculations, except in the total number of the cows. The few cows in the herd that were treated with antimicrobial agents for diseases other than mastitis were not included in the study material at all, and were not included in the total number of animals in this study.

\section{Milk Samples}

Two weeks before the expected calving and on the day of calving, milk samples were taken aseptically from every udder quarter for bacteriological examination. All quarters were then sampled for bacteriological analysis and for determination of the SCC every $4 \mathrm{wk}$ until the end of lactation or until the cow left the herd. The SCC was not determined from the samples before calving and at calving, and the regular sampling started from 2 to 4 wk after calving. The samples were taken in the afternoon before the evening milking.

The SCC samples were sent to the laboratory of Valio Ltd. (Helsinki, Finland), where the milk SCC was measured with a Fossomatic instrument (Foss Electric, Hillerød, Denmark). The milk samples for bacteriological examination were cultured using standard methods recommended by the National Mastitis Council (Hogan et al., 1999). Coagulase-negative staphylococci were distinguished from Staphylococcus aureus using an agglutination test (Slidex Staph-Plus, bioMérieux, Marcy l'Etoile, France). Potential test-negative isolates with Staph. aureus-like colony morphology were further tested with the tube coagulase test. The CNS isolates were analyzed to the species level with the API Staph ID 32 test (API; bioMérieux) and the apiweb software (https://apiweb.biomerieux.com). The isolates with API results of $>90 \%$ probability were named by species. The CNS isolates were then frozen (Protect Bacterial Preservers, Technical Service Consultants Ltd., Heywood, $\mathrm{UK})$ and stored at $-80^{\circ} \mathrm{C}$.

\section{Amplified Fragment Length Polymorphism Analysis}

For amplified fragment length polymorphism analysis (AFLP), the CNS isolates were recultured on blood agar, and bacterial DNA was isolated using the EasyDNA kit for genomic DNA isolation (Invitrogen Life Technologies, Carlsbad, CA). The AFLP was done as described by Keto-Timonen et al. (2003), with slight modifications. Briefly, DNA was digested with $15 \mathrm{U}$ of both HindIII and MseI (New England Biolabs, Beverly, MA) and ligated with restriction site-specific Hind (MWG-Biotech AG, Ebersberg, Germany) and Mse (Oligomer Oy, Helsinki, Finland) adapters. The nondiluted restriction fragments with specific adapters were amplified by preselective PCR by Hind- 0 and Mse- 0 primers (primers without selective extension; Oligomer $\mathrm{Oy})$. The products were diluted with sterile, distilled deionized water (1:20) before the selective amplification, in which FAM-labeled Hind-G and nonlabeled Mse-C primers were used (Oligomer Oy). Selective amplification products $(0.5 \mu \mathrm{L})$ were mixed with $12 \mu \mathrm{L}$ of HI-DI formamide and $0.4 \mu \mathrm{L}$ of GeneScan 500 LIZ Size Standard (Applied Biosystems, Foster City, CA), denatured at $95^{\circ} \mathrm{C}$ for $2 \mathrm{~min}$, and placed on ice. Amplification products were detected on an ABI Prism 310 DNA sequencer (Applied Biosystems) according to the manufacturer's instructions. Data collection, preprocessing, and fragment sizing were done using 310 Data Collection 3.0.0 and GeneScan 2.1 Analysis software (Applied Biosystems). The data were imported into BioNumerics 4.5 (Applied Maths, Kortrijk, Belgium). Levels of similarity between the fingerprint profiles were calculated using Pearson correlation, and unweighted pair group method by using average linkages (UPGMA) clustering was applied for the construction of the dendrograms.

The AFLP patterns of the isolates were compared with patterns of 49 Staphylococcus reference strains (Table 1). Clusters containing a type strain were considered species-specific at a similarity level of $>50 \%$ of patterns. One bacterial strain was used as an internal control and included in all experiment runs. The similarities between its pattern profiles were usually above $90 \%$ but at least $85 \%$ in the cluster deduced using the Pearson correlation and UPGMA. Infection was determined as persistent if CNS growth was detected in at 
Table 1. Staphylococcus type and reference strains used in the comparisons of amplified fragment length polymorphism patterns

\begin{tabular}{|c|c|}
\hline Staphylococcus species & $\begin{array}{l}\text { Type or } \\
\text { reference } \\
\text { strain }\end{array}$ \\
\hline Staph. aureus ssp. anaerobicus & DSM $20714^{\mathrm{T}}$ \\
\hline Staph. aureus ssp. aureus & DSM $20231^{\mathrm{T}}$ \\
\hline Staph. arlettae & DSM $20672^{\mathrm{T}}$ \\
\hline Staph. auricularis & DSM $20609^{T}$ \\
\hline Staph. capitis ssp. capitis & DSM $20326^{\mathrm{T}}$ \\
\hline Staph. capitis ssp. ureolyticus & DSM $6717^{\mathrm{T}}$ \\
\hline Staph. caprae & DSM $20608^{\mathrm{T}}$ \\
\hline Staph. carnosus ssp. carnosus & DSM $20501^{\mathrm{T}}$ \\
\hline Staph. carnosus ssp. utilis & DSM $11676^{\mathrm{T}}$ \\
\hline Staph. caseolyticus (Macrococcus caseolyticus) & DSM $20597^{\mathrm{T}}$ \\
\hline Staph. chromogenes & DSM $20454^{\mathrm{T}}$ \\
\hline Staph. cohnii ssp. cohnii & DSM $20260^{\mathrm{T}}$ \\
\hline Staph. cohnii ssp. urealyticum & DSM $6718^{\mathrm{T}}$ \\
\hline Staph. condimenti & DSM $11674^{\mathrm{T}}$ \\
\hline Staph. epidermidis & DSM $20044^{\mathrm{T}}$ \\
\hline Staph. equorum ssp. equorum & DSM $20674^{\mathrm{T}}$ \\
\hline Staph. equorum ssp. linens & DSM $15097^{\mathrm{T}}$ \\
\hline Staph. felis & DSM $7377^{\mathrm{T}}$ \\
\hline Staph. fleurettii & DSM $13212^{\mathrm{T}}$ \\
\hline Staph. gallinarum & DSM $20610^{\mathrm{T}}$ \\
\hline Staph. haemolyticus & DSM $20263^{\mathrm{T}}$ \\
\hline Staph. hominis ssp. hominis & DSM $20328^{\mathrm{T}}$ \\
\hline Staph. hominis ssp. novobiosepticus & DSM $15614^{\mathrm{T}}$ \\
\hline Staph. hyicus & DSM $20459^{\mathrm{T}}$ \\
\hline Staph. intermedius & DSM $20373^{\mathrm{T}}$ \\
\hline Staph. kloosii & DSM $20676^{\mathrm{T}}$ \\
\hline Staph. lentus & DSM $20352^{\mathrm{T}}$ \\
\hline Staph. lugdunensis & DSM $4804^{\mathrm{T}}$ \\
\hline Staph. lutrae & DSM $10244^{\mathrm{T}}$ \\
\hline Staph. muscae & DSM $7068^{\mathrm{T}}$ \\
\hline Staph. nepalensis & DSM $15150^{\mathrm{T}}$ \\
\hline Staph. pasteuri & DSM $10656^{\mathrm{T}}$ \\
\hline Staph. piscifermentans & DSM $7373^{\mathrm{T}}$ \\
\hline Staph. pulvereri (Staph. vitulinus) & DSM $9930^{\mathrm{T}}$ \\
\hline Staph. saprophyticus ssp. bovis & CCUG $36975^{\mathrm{T}}$ \\
\hline Staph. saprophyticus ssp. saprophyticus & DSM $20229^{\mathrm{T}}$ \\
\hline Staph. schleiferi ssp. coagulans & DSM $6628^{\mathrm{T}}$ \\
\hline Staph. schleiferi ssp. schleiferi & DSM $4807^{\mathrm{T}}$ \\
\hline Staph. sciuri ssp. carnaticus & DSM $15613^{\mathrm{T}}$ \\
\hline Staph. sciuri ssp. rodentium & DSM $16827^{\mathrm{T}}$ \\
\hline Staph. sciuri ssp. sciuri & DSM $20345^{\mathrm{T}}$ \\
\hline Staph. simiae & CCUG $51256^{\mathrm{T}}$ \\
\hline Staph. simulans & DSM $20322^{\mathrm{T}}$ \\
\hline Staph. simulans & CCUG 46177 \\
\hline Staph. succinus ssp. casei & DSM $15096^{\mathrm{T}}$ \\
\hline Staph. succinus ssp. succinus & DSM $14617^{\mathrm{T}}$ \\
\hline Staph. warneri & DSM $20316^{\mathrm{T}}$ \\
\hline Staph. vitulinus & DSM $15615^{\mathrm{T}}$ \\
\hline Staph. xylosus & DSM $20266^{\mathrm{T}}$ \\
\hline
\end{tabular}

least 3 consecutive or almost consecutive samplings (one bacterially negative sample was acceptable between 2 samples with growth of the same CNS strain), and the isolates from these samplings possessed highly similar AFLP patterns (corresponding similarity level of patterns with the level of the internal control). Under these circumstances the isolates were considered to represent the same clonal lineage.

\section{Statistical Analyses}

For each quarter, geometric mean of SCC was calculated. For quarters infected with CNS during lactation, geometric means were also calculated from samplings at which CNS were isolated. A mean and a median of the geometric means of quarters were calculated for the following groups: 1) quarters with no bacterial growth during the entire lactation, 2) quarters with a transient CNS infection during lactation, 3) quarters with a persistent CNS infection during lactation: geometric mean of the entire lactation, 4) quarters with a persistent CNS infection during lactation: geometric mean of the samples with CNS growth, and 5) quarters with CNS growth before calving, at calving, or both, but no bacterial growth during the lactation. For quarters with a transient CNS infection, a mean, and a median of the samplings with CNS growth were calculated.

\section{RESULTS}

\section{CNS Infections During Lactation}

Infection with CNS was detected during lactation in $63(19.2 \%)$ of 328 quarters (Table 2). Thirty of these 63 quarters were in 22 primiparous cows and 33 in 25 multiparous cows. Thus, the incidence of CNS infection during lactation was $25.0 \%$ for quarters in first lactation and $15.9 \%$ for quarters in later lactations. All infections were associated with subclinical or mildly clinical mastitis. Before parturition, at parturition, or both, 57 quarters were infected with CNS (37.5\% of first-lactation quarters and $5.8 \%$ of subsequent-lactation quarters). In 28 of these 57 quarters, CNS infection was detected again during the lactation. Thirty-two quarters were infected at the beginning of lactation and 33 quarters were infected for the first time later during lactation. For cows in first lactation, $74.2 \%$ of quarters were infected at the beginning of lactation, and for cows in later lactations, $20.0 \%$ of quarters were infected at the beginning of lactation.

Infection persisted in 29 quarters (in $13.3 \%$ of quarters in first lactation and $6.3 \%$ of quarters in later lactations) and was transient in 34 quarters (11.7\% of quarters in first lactation and $9.6 \%$ of quarters in later lactations). During a persistent infection, the same CNS strain was isolated from the same quarter from 3 to 12 times (in 10 of 29 quarters $\geq 10$ times; in 24 of 29 quarters $\geq 5$ times). Most infections persisted from the detection of the infection to the end of the lactation or culling of the cow. In only 2 quarters was CNS growth not detected in 2 and 3 last samplings, respectively. In 14 quarters with transient infection, the causative strain was isolated twice and in 20 quarters only once. The bacterial count in all persistent infections was nearly 
Table 2. Intramammary CNS infection status of the 328 quarters of 82 cows (30 primiparous, 52 multiparous) before calving, at calving, or both, and during lactation ${ }^{1}$

\begin{tabular}{lccc}
\hline Status & $\begin{array}{c}\text { No CNS growth } \\
\text { before/at calving } \\
\mathrm{n}=247 \text { quarters }\end{array}$ & $\begin{array}{c}\text { CNS growth } \\
\text { before/at calving } \\
\mathrm{n}=57 \text { quarters }\end{array}$ & $\begin{array}{c}\text { Missing sample } \\
\text { before/at calving } \\
\mathrm{n}=24 \text { quarters }\end{array}$ \\
\hline No CNS infection during lactation, quarters & 216 & 29 & 20 \\
Persistent CNS infection during lactation, quarters & 14 & 13 & 2 \\
Transient CNS infection during lactation, quarters & 17 & 15 & 2 \\
\hline
\end{tabular}

${ }^{1}$ Infections were determined as persistent if the same CNS strain was isolated in $\geq 3$ consecutive samplings. Quarters were sampled every 4 wk.

always $>10 \mathrm{cfu} / 0.01 \mathrm{~mL}$; in transient infections, the bacterial colony count was $<10 \mathrm{cfu} / 0.01 \mathrm{~mL}$ in half of the quarters.

\section{SCC}

The mean and the median of geometric means of SCC of quarters with no bacterial growth throughout the lactation were 65,000 cells $/ \mathrm{mL}$ [95\% confidence interval (CI): $44,700-85,300$ cell $\mathrm{s} / \mathrm{mL}]$ and 34,300 cells $/ \mathrm{mL}$ (lower quartile 21,700; upper quartile 61,700 cells $/ \mathrm{mL}$ ), respectively. The mean and the median of geometric means of SCC of quarters with persistent CNS infection were, during the infection, 657,600 cells $/ \mathrm{mL}$ (95\% CI: $223,400-1,091,800$ cells $/ \mathrm{mL}$ ) and 355,400 cells $/ \mathrm{mL}$ (lower quartile 180,500; upper quartile 765,600 cells/ $\mathrm{mL}$ ), and, for the whole lactation, 317,500 cells $/ \mathrm{mL}$ (95\% CI: $209,500-425,500$ cell $\mathrm{s} / \mathrm{mL}$ ) and 202,800 cells $/ \mathrm{mL}$ (lower quartile 63,000; upper quartile 440,500 cells/ $\mathrm{mL}$ ), respectively. The mean and the median of SCC of quarters with transient CNS infection were, during the infection, 619,100 cells/mL (95\% CI: $0-1,267,300$ cells/ $\mathrm{mL}$ ) and 133,500 cells/mL (lower quartile 59,300; upper quartile 315,400 cell $/ \mathrm{mL}$ ), respectively. The mean and the median of geometric means for the whole lactation were 292,200 cells/mL (95\% CI: 7,600-576,700 cells/ $\mathrm{mL}$ ) and 50,400 cells/mL (lower quartile 26,600; upper quartile 162,200 cells $/ \mathrm{mL}$ ), respectively. The mean and the median of geometric means of SCC of quarters with CNS growth before calving, at calving, or both, but no growth during the lactation, were 72,700 cells/mL (95\% CI: $46,600-98,900$ cells $/ \mathrm{mL}$ ) and 41,800 cell $/ \mathrm{mL}$ (lower quartile 29,400 ; upper quartile 84,800 cells $/ \mathrm{mL}$ ), respectively.

\section{CNS Species According to API Test and AFLP Patterns}

According to the API results, the predominant CNS species both in transient and persistent infections was Staph. chromogenes, followed by Staph. simulans (Ta- ble 3 ). The API test was unable to identify $28.6 \%$ of the isolates with an acceptable identification result set at $90 \%$. The most common species in the samples taken before or at calving was Staph. chromogenes.

The biggest cluster of AFLP patterns was that including the Staph. chromogenes type strain, followed by clusters including the Staph. haemolyticus, Staph. simulans, and Staph. epidermidis type strains (Table 3). These clusters were represented in both persistent and transient infections in similar proportions. In samples taken before or at calving, clusters including Staph. chromogenes and Staph. simulans type strains dominated, and Staph. haemolyticus and Staph. epidermidis were not isolated. The similarity levels of clusters considered to represent Staph. chromogenes, Staph. haemolyticus, Staph. simulans, Staph. epidermidis, Staph. warneri, Staph. xylosus, and Staph. cohnii ssp. urealyticum were $60.3,73.1,72.5,72.3,54.0,68.2$, and $75.2 \%$, respectively. The agreement between species identification results of API and AFLP analyses is shown in Table 4.

\section{DISCUSSION}

About half of the CNS infections persisted for long periods during the lactation. Most of the quarters with persistent infections remained infected from the detection of infection until the end of lactation. Based on the AFLP patterns, one clone was often isolated from the quarter before and after calving, but about half of the quarters became infected for the first time later during lactation. Multiparous cows were in general infected with CNS in later lactation, whereas primiparous cows usually were infected already in the beginning of lactation. The same has also been shown by Gröhn et al. (2004). In our study, infection was defined as persistent when CNS with identical AFLP patterns were isolated from a quarter at least 3 times; that is, the infection persisted for 2 mo or longer. In $41 \%$ of the transient infections, isolates considered to represent the same clonal lineage were detected twice, the infection thus lasting at least $1 \mathrm{mo}$. 
Table 3. Coagulase-negative staphylococci species identified with the API Staph ID 32 test (API) and with amplified fragment length (AFLP) analysis ${ }^{1}$

\begin{tabular}{|c|c|c|c|c|c|c|c|c|c|c|c|c|}
\hline \multirow[b]{3}{*}{ CNS species } & \multicolumn{4}{|c|}{$\begin{array}{l}\text { Infection before } \\
\text { or at calving }\end{array}$} & \multicolumn{4}{|c|}{$\begin{array}{l}\text { Persistent infection } \\
\text { during lactation }\end{array}$} & \multicolumn{4}{|c|}{$\begin{array}{l}\text { Transient infection } \\
\text { during lactation }\end{array}$} \\
\hline & \multicolumn{2}{|c|}{ API } & \multicolumn{2}{|c|}{ AFLP } & \multicolumn{2}{|c|}{ API } & \multicolumn{2}{|c|}{ AFLP } & \multicolumn{2}{|c|}{ API } & \multicolumn{2}{|c|}{ AFLP } \\
\hline & $\mathrm{n}$ & $\%$ & $\mathrm{n}$ & $\%$ & $\mathrm{n}$ & $\%$ & $\mathrm{n}$ & $\%$ & $\mathrm{n}$ & $\%$ & $\mathrm{n}$ & $\%$ \\
\hline Staphylococcus capitis & & & & & & & & & 1 & 2.9 & & \\
\hline Staphylococcus chromogenes & 28 & 49.1 & 30 & 52.6 & 11 & 37.9 & 12 & 41.4 & 6 & 17.6 & 10 & 29.4 \\
\hline Staphylococcus cohnii & 1 & 1.8 & 2 & 3.5 & 1 & 3.4 & 1 & 3.4 & & & & \\
\hline Staphylococcus epidermidis & & & & & 2 & 6.9 & 4 & 13.8 & 1 & 2.9 & 2 & 5.9 \\
\hline Staphylococcus equorum & 1 & 1.8 & & & & & & & 1 & 2.9 & & \\
\hline Staphylococcus haemolyticus & 1 & 1.8 & 6 & 10.5 & & & 3 & 10.3 & 3 & 8.8 & 11 & 32.4 \\
\hline Staphylococcus simulans & 13 & 22.8 & 13 & 22.8 & 7 & 24.1 & 6 & 20.7 & 3 & 8.8 & 3 & 8.8 \\
\hline Staphylococcus warneri & 3 & 5.2 & & & 4 & 13.8 & 1 & 3.4 & 4 & 11.8 & 1 & 2.9 \\
\hline Staphylococcus xylosus & & & 1 & 1.8 & & & & & 1 & 2.9 & 2 & 5.9 \\
\hline Staphylococcus spp. $^{2}$ & 10 & 17.5 & 5 & 8.8 & 4 & 13.8 & 2 & 6.9 & 14 & 41.2 & 4 & 11.8 \\
\hline Total & 57 & 100.0 & 57 & 100.0 & 29 & 100.0 & 29 & 100.0 & 34 & 100.0 & 34 & 100.0 \\
\hline
\end{tabular}

${ }^{1}$ The CNS strains were collected from bovine quarters before and at calving and from persistent and transient infections during lactation. Quarters were sampled every 4 wk. Fifty-seven infections were detected before calving, at calving, or both, and 28 of them were detected again in later lactation. Twenty-nine persistent and 34 transient infections were detected during lactation. The infection was determined as persistent if the same CNS strain was isolated in $\geq 3$ consecutive samplings.

${ }^{2}$ Species not identified.

Earlier evidence shows that CNS cause chronic IMI, and at least some of the CNS infections persist (Aarestrup and Jensen, 1997; Laevens et al., 1997a; Chaffer et al., 1999; Taponen et al., 2006). Differences in persistence between CNS species may exist. Aarestrup and Jensen (1997) followed quarters of heifers from 4 wk prepartum until 4 wk after calving. They showed that infections caused by Staph. chromogenes disappeared shortly after parturition, and infections caused by Staph. epidermidis were transient. In contrast, infections caused by Staph. simulans were found to persist for longer. The persistence of the same Staph. simulans clone was later confirmed by ribotyping (Aarestrup et al., 1999). We did not detect such a clear difference in persistence between the 2 dominant species, Staph. chromogenes and Staph. simulans. In our study, in which cows were followed over the whole lactation, Staph. chromogenes infections persisted similarly to other CNS infections. Of the 22 Staph. chromogenes infections during lactation, $12(54.5 \%)$ persisted; of the 9 Staph. simulans infections, $6(66.7 \%)$ persisted. Staphylococcus epidermidis was also a cause of persistent infections. However, the limited number of infected quarters in the study of Aarestrup and Jensen (1997) and in our study does not allow a valid comparison between species.

The same CNS species and isolates with similar AFLP patterns were found in both persistent and tran-

Table 4. Agreement between CNS species identification results of API Staph ID 32 (API) and amplified fragment length polymorphism (AFLP) analyses ${ }^{1}$

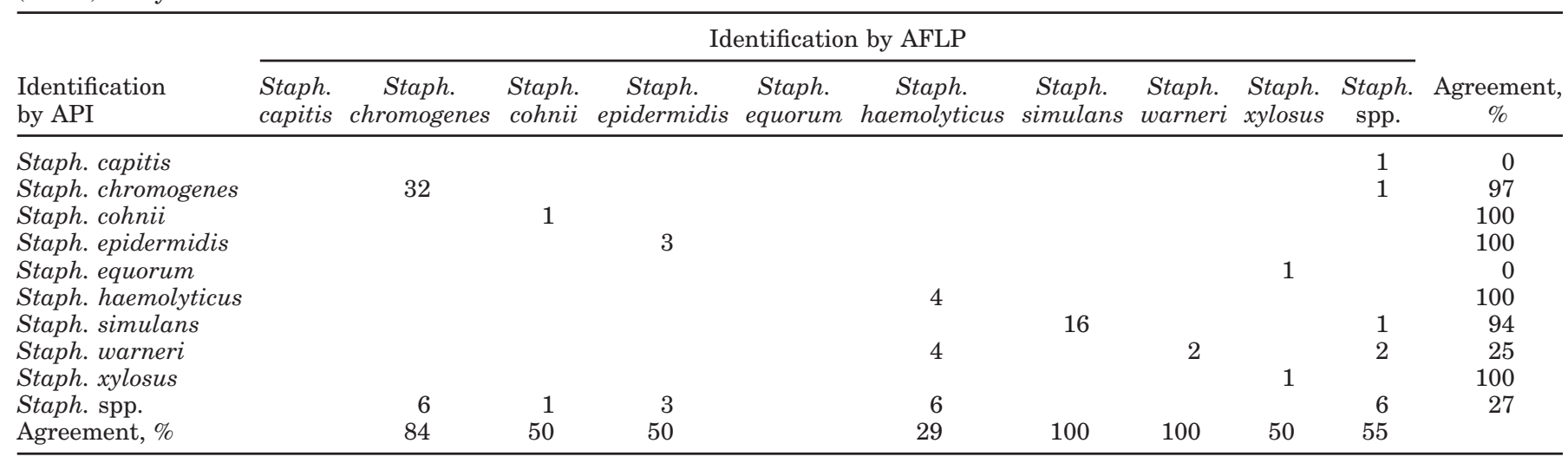

${ }^{1}$ The criteria for species identification were probability of API test result $>90 \%$ and similarity level of the AFLP pattern with the AFLP pattern of CNS type strain $>50 \%$. 
sient infections. This suggests that host-microbe interaction plays a key role in the genesis of infection. Heifers and primiparous cows were much more susceptible to CNS mastitis than were multiparous cows. Although this is commonly known, the reason for this phenomenon remains unclear. Some heifers and cows are able to eliminate the CNS infection whereas others are not, which is intriguing. Some factors of the host may interact with the ability of the bacteria to adhere to mammary gland cells. There may also be differences in the mastitis-causing bacteria, but very little is known about the factors determining virulence of CNS of bovine origin. Only a few reports describe potential virulence factors and mechanisms of bovine CNS infection (Mamo et al., 1988; Saa and Kruze, 1995; Zhang and Maddox, 2000; Almeida and Oliver, 2001; Anaya-López et al., 2006; Oliveira et al., 2006). Further studies are needed to elucidate the interactions between CNS and the bovine udder as well as differences in the virulence factors of different CNS species and strains.

The SCC in quarters infected with CNS was rather low compared with SCC values generally associated with infections caused by other common gram-positive mastitis pathogens such as Staph. aureus and streptococci. The SCC was, however, about 10-fold higher than that of healthy quarters, which typically remains below 50,000 cells $/ \mathrm{mL}$ (Barkema et al., 1999). We found that the SCC of a healthy quarter remained between 10,000 and 40,000 cells $/ \mathrm{mL}$ in both first and later lactations, whereas in CNS infections, the SCC was clearly elevated. The SCC in quarters with persistent CNS infection varied considerably from sampling to sampling, and the geometric means of quarters infected with CNS also varied. Compared with the study of Djabri et al. (2002), the mean SCC of quarters with CNS infection in our study was somewhat higher than the average $\mathrm{SCC}$ in that meta-analysis. Even a transient CNS infection caused a temporary increase in SCC, which was consistent with the report of Laevens et al. (1997b). Infection with CNS induces an immunological reaction in the udder and should not be considered merely teatcanal colonization or a normal situation for the udder. Some authors have suggested that infection with minor pathogens like Staph. chromogenes or other CNS and Corynebacterium spp. would be beneficial because it might protect the quarter from mastitis with major pathogens like Staph. aureus (Schukken et al., 1989; Matthews et al., 1990). Possible mechanisms for this effect could be increased SCC or bacteriocins produced by the bacteria (Matthews et al., 1990; De Vliegher et al., 2004). The possible protective effect of CNS IMI remains theoretical and we conclude that CNS infections should be dealt with as any IMI.
We used AFLP genotyping not only for differentiation of CNS strains, but also for species identification alongside API testing. Phenotypic methods have proved to be insufficient for identification of bovine CNS isolates (Bes et al., 2000; Taponen et al., 2006) and isolates of human origin (Heikens et al., 2005; Skow et al., 2005). At the moment, a feasible and reliable method for identification of all staphylococci at the species level does not exist. We tested AFLP analysis in identification of CNS species with promising results in our earlier study (Taponen et al., 2006). Moreover, in this study, the AFLP patterns of isolates formed clear clusters with similarity levels of $>50 \%$, and a type strain was included in most of the clusters. In AFLP, Pearson correlation, based on curves instead of bands, is usually used in numerical analyses. This method is very sensitive to variation, which is seen as the rather high variability percentage of the AFLP patterns of the internal control strain and the species-specific clusters. This has to be taken into account when the similarities of AFLP patterns of species and strains are evaluated. The API and AFLP analyses identified only $71.9 \%$ of the isolates identically. The predominant species, Staph. chromogenes and Staph. simulans, were generally identified identically by API and AFLP, but results for the less common species were often inconsistent. Further studies using polyphasic approaches are needed to solve the problems in identification of CNS species.

\section{CONCLUSIONS}

About half of the CNS infections during lactation persisted in the udder. Both persistent and transient CNS infections caused an immunological reaction in the udder, reflected as an increased SCC. Approximately $50 \%$ of the quarters in which a CNS infection was detected before or at calving would cure spontaneously during lactogenesis. In about half of the quarters in which a CNS infection was diagnosed, the infection was present for only a short time after calving and then disappeared.

\section{ACKNOWLEDGMENTS}

We thank Valio Ltd. for analysis of SCC, and Taina Lehto and Henna Niinivirta are thanked for excellent technical assistance with API and AFLP analyses. Financial support from the Walter Ehrström Foundation is gratefully acknowledged.

\section{REFERENCES}

Aarestrup, F. M., and N. E. Jensen. 1997. Prevalence and duration of intramammary infection in Danish heifers during the peripartum period. J. Dairy Sci. 80:307-312. 
Aarestrup, F. M., H. D. Larsen, and N. E. Jensen. 1999. Characterization of Staphylococcus simulans strains from cases of bovine mastitis. Vet. Microbiol. 66:165-170.

Almeida, R. A., and S. P. Oliver. 2001. Interaction of coagulasenegative staphylococcus species with bovine mammary epithelial cells. Microbiol. Pathogen. 31:205-212.

Anaya-López, J. L., O. E. Contreras-Guzmán, A. Cárabez-Trejo, V. M. Baizabal-Aguirre, J. E. López-Meza, J. J. Valdez-Alarcón, and A. Ochoa-Zarzosa. 2006. Invasive potential of bacterial isolates associated with subclinical bovine mastitis. Res. Vet. Sci. 81:358-361.

Barkema, H. W., H. A. Deluyker, Y. H. Schukken, and T. J. G. M. Lam. 1999. Quarter-milk somatic cell count at calving and at the first six milkings after calving. Prev. Vet. Med. 38:1-9.

Bes, M., V. Guérin-Faublée, H. Meugnier, J. Etienne, and J. Freney. 2000. Improvement of the identification of staphylococci isolated from bovine mammary infections using molecular methods. Vet. Microbiol. 71:287-294.

Chaffer, M., G. Leitner, M. Winkler, A. Glickman, O. Krifucks, E. Ezra, and A. Saran. 1999. Coagulase-negative staphylococci and mammary gland infections in cows. J. Vet. Med. B 46:707-712.

De Vliegher, S., H. W. Barkema, H. Stryhn, G. Opsomer, and A. de Kruif. 2005. Impact of early lactation somatic cell count in heifers on milk yield over the first lactation. J. Dairy Sci. 88:938-947.

De Vliegher, S., G. Opsomer, A. Vanrolleghem, L. A. Devriese, O. C. Sampimon, J. Sol, H. W. Barkema, F. Haesebrouck, and A. de Kruif. 2004. In vitro growth inhibition of major mastitis pathogens by Staphylococcus chromogenes originating from teat apices of dairy heifers. Vet. Microbiol. 101:215-221.

Djabri, B., N. Bareille, F. Beaudeau, and H. Seegers. 2002. Quarter milk somatic cell count in infected dairy cows: A meta-analysis. Vet. Res. 33:335-357.

Gröhn, Y. T., D. J. Wilson, R. N. González, J. A. Hertl, H. Schulte, G. Bennett, and Y. H. Schukken. 2004. Effect of pathogen-specific clinical mastitis on milk yield in dairy cows. J. Dairy Sci. 87:3358-3374

Heikens, E., A. Fleer, A. Paauw, A. Florin, and A. C. Fluit. 2005. Comparison of genotypic and phenotypic methods for specieslevel identification of clinical isolates of coagulase-negative staphylococci. J. Clin. Microbiol. 43:2286-2290.

Hogan, J. S., R. N. González, R. J. Harmon, S. C. Nickerson, S. P. Oliver, J. W. Pankey, and K. L. Smith. 1999. Laboratory Handbook on Bovine Mastitis. Rev. ed. National Mastitis Council, Madison, WI.

Honkanen-Buzalski, T., V. Myllys, and S. Pyörälä. 1994. Bovine clinical mastitis due to coagulase-negative staphylococci and their susceptibility to antimicrobials. J. Vet. Med. B. 41:344-350.

Keto-Timonen, R. O., T. J. Autio, and H. J. Korkeala. 2003. An improved amplified fragment length polymorphism (AFLP) protocol for discrimination of Listeria isolates. Syst. Appl. Microbiol. 26:236-244.

Laevens, H., H. Deluyker, L. A. Devriese, and A. de Kruif. 1997a. The influence of intramammary infections with Staphylococcus chromogenes and Staphylococcus warneri or haemolyticus on the somatic cell count in dairy cows. Pages 05.23.1-05.23.3. in Proc. Epidémiol. Santé Anim. International Society of Veterinary Epidemiology and Economy, Maison-Alfort, France.
Laevens, H., H. Deluyker, Y. H. Schukken, L. De Meulemeester, R. Vandermeersch, E. De Muêlenaere, and A. De Kruif. 1997b. Influence of parity and stage of lactation on the somatic cell count in bacteriologically negative dairy cows. J. Dairy Sci. 80:32193226.

Macovec, J. A., and P. L. Ruegg. 2003. Results of milk samples submitted for microbiological examination in Wisconsin from 1994 to 2001. J. Dairy Sci. 86:3466-3472.

Mamo, W., G. Froman, and T. Waldstrom. 1988. Interaction of subepithelial connective tissue components with Staphylococcus aureus and coagulase-negative staphylococci from bovine mastitis. Vet. Microbiol. 18:163-176.

Matthews, K. R., R. J. Harmon, and B. A. Smith. 1990. Protective effect of Staphylococcus chromogenes infection against Staphylococcus aureus infection in the lactating bovine mammary gland. J. Dairy Sci. 73:3457-3462.

Nevala, M., S. Taponen, and S. Pyörälä. 2004. Bacterial etiology of bovine clinical mastitis-Data from Saari Ambulatory Clinic in 2002-2003. Suomen Eläinlääkärilehti 110:363-369.

Oliveira, M., R. Bexiga, S. F. Nunes, C. Carneiro, L. M. Cavaco, F. Bernardo, and C. L. Vilela. 2006. Biofilm-forming ability profiling of Staphylococcus aureus and Staphylococcus epidermidis mastitis isolates. Vet. Microbiol. 118:133-140.

Pitkälä, A., M. Haveri, S. Pyörälä, V. Myllys, and T. HonkanenBuzalski. 2004. Bovine mastitis in Finland 2001-Prevalence, distribution of bacteria, and antimicrobial resistance. J. Dairy Sci. 87:2433-2441.

Saa, E., and J. Kruze. 1995. Virulence factors of coagulase-negative staphylococcus of human and bovine origin. Rev. Latinoam. Microbiol. 37:201-208.

Schukken, Y. H., D. Van de Geer, F. J. Grommers, J. A. Smit, and A. Brand. 1989. Intramammary infections and risk factors for clinical mastitis in herds with low somatic cell counts in bulk milk. Vet. Rec. 125:393-396.

Skow, Á., K. A. Mangold, M. Tajuddin, A. Huntington, B. Fritz, R. B. Jr. Thomson, and K. L. Kaul. 2005. Species-level identification of staphylococcal isolates by real-time PCR and melt curve analysis. J. Clin. Microbiol. 43:2876-2880.

Taponen, S., H. Simojoki, M. Haveri, H. D. Larsen, and S. Pyörälä. 2006. Clinical characteristics and persistence of bovine mastitis caused by different species of coagulase-negative staphylococci identified with API or AFLP. Vet. Microbiol. 115:199-207.

Tenhagen, B.-A., G. Köster, J. Wallmann, and W. Heuwieser. 2006. Prevalence of mastitis pathogens and their resistance against antimicrobial agents in dairy cows in Brandenburg, Germany. J. Dairy Sci. 89:2542-2551.

Timms, L. L., and J. H. Schultz. 1987. Dynamics and significance of coagulase-negative staphylococcal intramammary infections. J. Dairy Sci. 70:2648-2657.

Waage, S., T. Mørk, A. Røros, D. Aasland, A. Hunshamar, and S. A. Ødegaard. 1999. Bacteria associated with clinical mastitis in dairy heifers. J. Dairy Sci. 82:712-719.

Wilson, D. J., R. N. González, and H. H. Das. 1997. Bovine mastitis pathogens in New York and Pennsylvania: Prevalence and effects on somatic cell count and milk production. J. Dairy Sci. 80:2592-2598.

Zhang, S., and C. W. Maddox. 2000. Cytotoxic activity of coagulasenegative staphylococci in bovine mastitis. Infect. Immun. 68:1102-1108. 